\title{
PENGARUH PROFITABILITAS DAN LIKUIDITAS TERHADAP RETURN SAHAM PERBANKAN YANG LISTING DI BURSA EFEK INDONESIA
}

\author{
Trisna Wijayanti ${ }^{(1)}$, Deviana Sari ${ }^{(2)}$ \\ Fakultas Ekonomi Universitas Sang Bumi Ruwa Jurai \\ trisna.wijayanti@fe.saburai.ac.id,deviana.sari@fe.saburai.ac.id
}

\begin{abstract}
Abstrak. Suatu bank harus memiliki likuiditas dan profitabilitas yang baik agar bank tersebut mendapatkan kepercayaan investor dan calon investor serta nasabah, likuiditas diperlukan agar dana selalu tersedia saat nasabah ingin menarik dana dari bank, sedangkan profitabilitas menunjukkan tingkat laba suatu bank. Populasi dalam penelitian ini adalah seluruh perbankan yang terdaftar di Bursa Efek Jakarta sebanyak 29 bank dan hanya 22 bank yang dijadikan sample penelitian sesuai kreteria yang telah ditentukan. Berdasarkan hasil perhitungan, diperoleh angka $t_{\text {hitung }}$ Variable Profitabilitas yang diukur dengan Return On Equity $\left(\mathrm{X}_{1}\right)$ sebesar 3,440 $>t_{\text {tabel }}$ sebesar 2,0930, sehingga $\mathrm{H}_{\mathrm{a}}$ diterima dan $\mathrm{H}_{0}$ ditolak. Artinya, pengaruh yang signifikan Profitabilitas yang diukur dengan Return On Equity (ROE) terhadap Return saham. Hal ini sesuai dengan nilai signifikansi sebesar 0,001 yang lebih kecil dari 0,05. Dengan demikian, Profitabilitas yang tinggi akan dapat meningkatkan Return saham perbankan. Berdasarkan hasil perhitungan analisis regresi linier menunjukkan nilai $F_{\text {hitung }}$ adalah 8.380 dengan tingkat signifikansi 0,001. Sedangkan $F_{\text {tabel }}$ pada tingkat kepercayaan $95 \%(\alpha=0,05)$ dengan $n-1-\mathrm{k}$ adalah 3,52. Oleh karena pada perhitungan $F_{\text {hitung }}>F_{\text {tabel }}$ yakni $8.380>3,52$ sesuai dengan nilai signifikansi sebesar 0,001 yang lebih kecil dari 0,05. Maka hal ini menunjukkan bahwa pengaruh variable independen oleh profitabilitas dan likuiditas berpengaruh secara parsial dan simultan terhadap Return saham dapat diterima secara keseluruhan.
\end{abstract}

Kata kunci: Likuiditas, Listing, Profitabilitas, Return, Saham.

\section{PENDAHULUAN}

Pada Era globalisasi saat ini memiliki dampak bagi perkembangan ekonomi dunia. Berbagai perusahaan dengan giat melakukan ekspansi setelah terhempasnya krisis global, dengan cara memperluas usahanya dan memperbaiki perekonomian dalam memasuki lingkup ekonomi global sejalan dengan perkembangan ekonomi dunia yang semakin meningkat. Upaya ekspansi perusahaan ini antara lain dilakukan dengan kegiatan penanaman modal. Dengan menerbitkan saham dan memberikan return saham yang besar tentu akan memicu para calon investor khususnya di Indonesia untuk berinvestasi, selain untuk memperkuat modal perusahaan dampak investasi juga sangat berperan penting dalam meningkatkan perekonomian khususnya di Indonesia. Besar dan berkembangnya kebutuhan modal usaha perusahaan dipengaruhi oleh berbagai faktor diantaranya: perkembangan ekonomi sosial masyarakat, persaingan antar perusahan, perkembangan teknik dan sistem ekspansi perusahaan baik eksternal maupun internal.

Pertumbuhan eksternal apabila perusahaan menggunakan sumber pembiayaan baru dari luar seperti menerbitkan saham baru untuk memenuhi kebutuhan jangka panjang atau untuk mendanai suatu proyek baru. Pertumbuhan secara internal yaitu dengan menahan sebagian atau semua keuntungan perusahaan yang nantinya akan memberikan keuntungan yang lebih tinggi dimasa yang akan datang melalui peningkatan laba dan dividen dimasa 
depan. Para pemegang saham dan calon investor sangat memperhatikan profitabilitas suatu perusahaan karena akan berkaitan dengan harga saham serta deviden yang akan diterima.

Dalam melaksanakan analisis profitabilitas, dilaksanakan terhadap rasiorasio yang menunjukkan hasil akhir dari sejumlah kebijakan dan keputusankeputusan. (Detak Prapanca. 2006. Pengaruh Profitabilitas Terhadap Return Saham Pada Bank Yang Go Publik di Bursa Efek Jakarta). Tidak hanya mementingkan Profitabilitas, namun dalam hal ini investor ataupun pengguna jasa lainnya juga mementingkan tingkat likuiditas sebuah bank. Bank wajib menyediakan likuiditas tersebut dengan cukup dan mengelolanya dengan baik, karena apabila likuiditas tersebut terlalu kecil maka akan mengganggu kegiatan operasional perbankan.

Likuiditas menunjukkan kemampuan bank dalam memenuhi kewajiban jangka pendeknya. Salah satu cara untuk memperkuat posisi likuiditas adalah dengan menerbitkan saham. Semakin besar likuiditas Bank maka semakin baik pula kinerja jangka pendek Bank tersebut, sehingga investor dan calon investor tersebut akan semakin percaya kepada bank tersebut, hal tersebut akan berimbas pada peningkatan harga saham, dan akan berakibat pada naiknya Return saham.

Likuiditas sangat membantu bagi manajemen untuk mengecek efisiensi modal kerja yang digunakan dalam perusahaan, juga penting bagi pemegang saham yang ingin mengetahui prospek dari deviden dimasa yang akan datang (Primandoko, 2005).

Suatu bank juga harus memiliki likuiditas dan profitabilitas yang baik agar bank tersebut mendapatkan kepercayaan dari masyarakat, likuiditas diperlukan agar dana selalu tersedia saat nasabah ingin menarik dana dari bank, sedangkan profitabilitas menunjukkan tingkat laba suatu bank.

Menurut Suad Husnan dalam "Dasardasar Teori Portofolio dan Analisis Sekuritas" jika profitabilitas perusahaan meningkat maka dampak akhirnya adalah peningkatan profitabilitas pemegang saham. Sedang likuiditas sangat membantu bagi manajemen untuk mengecek efisiensi modal kerja yang digunakan dalam perusahaan, juga penting bagi pemegang saham yang ingin mengetahui prospek dari deviden di masa datang (Primandoko, 2005).

Berdasarkan penelitian terdahulu diketahi bahwa terdapat likuiditas dan profitabilitas memiliki pengaruh terhadap Return saham (Primandoko, 2005). Dengan adanya penerbitan saham terutama perbankan serta memiliki tingkat keuntungan yang menjanjikan dan tingkat likuiditas yang baik akan menarik para inverstor untuk berinvestasi maka akan memperkuat keuangan suatu perbankan dan semakin dipercaya oleh masyarkat.

\section{KAJIAN TEORI}

\section{Pengertian Bursa Efek}

Bursa efek atau bursa saham adalah sebuah pasar yang berhubungan dengan pembelian dan penjualan efek perusahaan yang sudah terdaftar di bursa itu. Bursa efek tersebut, bersama-sama dengan pasar uang merupakan sumber utama permodalan eksternal bagi perusahaan dan pemerintah. Biasanya terdapat suatu lokasi pusat, setidaknya untuk catatan, namun perdagangan kini semakin sedikit dikaitkan dengan tempat seperti itu, karena bursa saham modern kini adalah jaringan elektronik, yang memberikan keuntungan dari segi kecepatan dan biaya transaksi.

Karena pihak pihak yang bertransaksi tidak perlu saling tahu lawan transaksinya, perdagangan dalam bursa hanya dapat 
dilakukan oleh seorang anggota, sang pialang saham. Permintaan dan penawaran dalam pasar-pasar saham didukung faktorfaktor yang, seperti halnya dalam setiap pasar bebas, memengaruhi harga saham (lihat penilaian saham).

\section{Persyaratan Listing di Bursa Efek (Pencatatan Saham)}

Perusahaan harus memenuhi syarat sebuah bursa saham agar saham mereka dapat dilist dan diperdagangkan di sana. Ini karena saham ini akan diperjualbelikan tanpa diperiksa keabsahannya, tanpa Due Diligence lagi. Bursa harus melakukan Due Diligence untuk publik. Contohnya, agar dapat dicatat dalam NYSE (Bursa Saham New York), sebuah perusahaan mesti telah menerbitkan setidaknya 1 juta saham seharga US\$100 juta dan mesti telah mendapatkan lebih dari US\$10 juta dalam tiga tahun terakhir.

\section{Pengertian Bank}

Menurut UU RI No 10 Tahun 1998 tanggal 10 November 1998 tentang perbankan, dapat disimpulkan bahwa usaha perbankan meliputi tiga kegiatan, yaitu menghimpun dana,menyalurkan dana, dan memberikan jasa bank lainnya. Kegiatan menghimpun dan menyalurkan dana merupakan kegiatan pokok bank sedangkan memberikan jasa bank lainnya hanya kegiatan pendukung. Kegiatan menghimpun dana, berupa mengumpulkan dana dari masyarakat dalam bentuk simpanan giro, tabungan, dan deposito. Biasanya sambil diberikan balas jasa yang menarik seperti, bunga dan hadiah sebagai rangsangan bagi masyarakat. Kegiatan menyalurkan dana, berupa pemberian pinjaman kepada masyarakat. Sedangkan jasa-jasa perbankan lainnya diberikan untuk mendukung kelancaran kegiatan utama tersebut.

\section{Pengertian Saham}

Saham adalah satuan nilai atau pembukuan dalam berbagai instrumen finansial yang mengacu pada bagian kepemilikan sebuah perusahaan. Dengan menerbitkan saham, memungkinkan perusahaan-perusahaan yang membutuhkan pendanaan jangka panjang untuk 'menjual' kepentingan dalam bisnis - saham (efek ekuitas) - dengan imbalan uang tunai. Ini adalah metode utama untuk meningkatkan modal bisnis selain menerbitkan obligasi. Saham dijual melalui pasar primer (primary market) atau pasar sekunder (secondary market).

\section{Pengertian Profitabilitas}

Profitabilitas merupakan alat yang digunakan untuk menganalisis kinerja manajemen, tingkat profitabilitas akan menggambarkan posisi laba perusahaan. Para investor di pasar modal sangat memperhatikan kemampuan perusahaan dalam menghasilkan dan meningkatkan laba, hal ini merupakan daya tarik bagi investor dalam melakukan jual beli saham, oleh karena itu manajemen harus mampu memenuhi target yang telah ditetapkan.

Gibson (2001), profitability is the ability of a firm to generate earnings. It is measured relative to a number of bases, such as assets, sales, and investment". Gibson mengartikan profitabilitas sebagai kemampuan suatu perusahaan untuk meningkatkan laba perusahaan, profitabilitas ini diukur dengan membandingkan laba yang diperoleh perusahaan dengan sejumlah perkiraan yang menjadi tolak ukur keberhasilan perusahaan seperti aktiva perusahaan, penjualan dan investasi. 


\section{Pengertian Likuiditas}

Menurut Martono dan Agus Harjito (2001), bahwa likuditas merupakan indikator perusahaan untuk membayar atau melunasi kewajiban-kewajiban finansialnya pada saat jatuh tempo dengan mempergunakan aktiva lancar yang tersedia. Secara umum, definisi likuiditas adalah kemampuan untuk memenuhi kebutuhan dana (cash flow) dengan segera dan dengan biaya yang sesuai (Putra, 2010).

Memiliki fungsi secara umum untuk mengatasi transaksi bisnis sehari-hari, mengatasi dana yang mendesak, memuaskan permintaan nasabah akan pinjaman dan memberikan fleksibilitas dalam meraih investasi menarik yang menguntungkan. Pengertian likuiditas bank yakni kemampuan bank untuk memenuhi kewajibannya, terutama kewajiban dana jangka pendek.

Likuditas menunjukkan kemampuan bank dalam memenuhi kewajiban jangka pendeknya. Semakin besar likuiditas Bank maka semakin baik pula kinerja jangka pendek Bank tersebut, sehingga investor dan nasabah Bank tersebut akan semakin percaya kepada bank tersebut, hal tersebut akan berimbas pada peningkatan harga saham, dan akan berakibat pada naiknya Return saham. Likuiditas sangat membantu bagi manajemen untuk mengecek efisiensi modal kerja yang digunakan dalam perusahaan, juga penting bagi pemegang saham yang ingin mengetahui prospek dari deviden dimasa yang akan datang (Munawir, 1998).

\section{METODE PENELITIAN}

\section{Objek Penelitian}

Objek penelitian ini adalah Bursa Efek Indonesia cabang Bandar Lampung dengan cara mengunjungi www.idx.co.id.

\section{Populasi}

Populasi penelitian ini merupakan seluruh perbankan yang go publik yang menerbitkan laporan keuangan selama tiga tahun terkahir berturut-turut pada Bursa Efek Indonesia.

\section{Sampel}

Sampel dalam penelitian ini diperoleh dengan metode purposive sampling. Seluruh perbankan yang masih tercatat ( $G o$ Public) di Bursa Efek Indonesia berjumlah sebanyak 29 bank yang selanjutnya berdasarkan metode tersebut maka sample penelitian yang dipilih dari perbankan yang terdaftar di Bursa Efek Indonesia dengan kriteria-kriteria yang telah ditentukan sebagai berikut:

1. Bank yang menyampaikan laporan keuangan secara berturut-turut pada tahun buku 2008-2010 yang menunjukkan Profitabilitas dan likuiditas bank yang tercermin pada Neraca dan Laporan Rugi-Laba tahun buku 2008-2010 yang telah diaudit oleh auditor independen.

2. Harga saham yang diterbitkan tiga tahun berturut-turut yakni tahun 20082010.

\section{Metode dan Teknik Pengumpulan Data}

Dalam penelitian ini, data terdiri dari laporan keuangan perusahaan yang go public yang telah diaudit oleh Akuntan Publik independen. Laporan keuangan tersebut dihimpun secara langsung dari Pusat Refrensi Pasar Modal di kantor Bursa Efek Indonesia dan adapun data rasio keuangan yang berasal dari Indonesia Capital Market Directory (ICMD). 


\section{Perumusan Model Analisis}

Pada penelitian ini akan diteliti pengaruh Variabel Profitabilitas dan Likuiditas bank terhadap Return Sahamnya, dimana dapat di jelaskan sebagai berikut :

Variabel Dependen : Return Saham Variabel Independen : Profitabilitas dan Likuiditas.

\section{Pengujian Hipotesis}

Alat uji yang digunakan untuk analisis penelitian ini adalah uji regresi linier berganda, untuk melihat pengaruh Profitabilitas (X1) yang diukur dengan Return On Equity dan Likuditas (X2) yang diukur dengan Current Ratio terhadap Return saham. Analisis regresi berganda digunakan dalam penelitian ini karena variable terikat yang dicari untuk dijelaskan hipotesis bergantung pada lebih dari satu variable bebas.

Model regresi berganda adalah sebagai berikut :

$$
Y=\beta_{0}+\beta_{1} X_{1}+\beta_{2} X_{2}
$$

Keterangan :

Y : Return Saham

$\beta_{0} \quad$ : Konstanta

$\mathrm{X}_{1} \quad$ : Return On Equity (ROE)

$\mathrm{X}_{2} \quad$ : Current Ratio (CR)

$\beta_{1-2} \quad$ : Koefisien variabel ke1 dan 2

\section{Uji Koefesiensi Determinasi (R2)}

Melihat berapa proporsi variasi dari variable bebas secara bersama-sama dalam mempengaruhi varibale tidak bebas. Menurut (Gujarati, dalam Mei Hotma Mariati Munte, 2009) dapat dihitung dengan rumus :

$$
R^{2}=\frac{J k_{R}}{J k_{y}}
$$

Keterangan :

$$
\begin{array}{ll}
\mathrm{JK}_{\mathrm{R}} & =\text { Jumlah kuadrat regresi } \\
\mathrm{JK}_{\mathrm{Y}} & =\text { Jumlah total kaudrat }
\end{array}
$$

\section{Uji (t) Parsial}

Untuk menguji kemaknaan koefisien parsial digunakan uji t. Pengambilan keputusan dilakukan berdasarkan perbandingan nilai $\mathrm{T}_{\text {hitung }}$ masing-masing koefisien regresi dengan nilai $T_{\text {tabel }}$ (nilai kritis) sesuai dengan taraf signifikansi yang digunakan. Uji t digunakan untuk menguji secara parsial antara variable bebas terhadap variable tidak bebas dengan asumsi bahwa variable lain dianggap konstan, dengan tingkat keyakinan $95 \%(\alpha=$ $0,05)$. Uji $t$ dapat dihitung dengan menggunakan rumus :

$$
T_{\text {hitung }}=\frac{b_{i}}{s b_{i}}
$$

Keterangan :

$b_{i} \quad$ : koefesien regresi masing-masing variable

$\mathrm{sb}_{\mathrm{i}} \quad$ : standar error masing-masing variable.

\section{Uji (F) Simultan}

Untuk membuktikan kebenaran hipotesis, peneliti menggunakan uji $\mathrm{F}$ yaitu untuk mengetahui sejauh mana variabel X1 dan X2 mampu menjelaskan atau berkontribusi terhadap variabel Return saham dengan cara membandingkan Fhitung dengan Ftabel. Dengan maksud menguji apakah secara simultan variable bebas berpengaruh terhadap variable tidak bebas, dengan tingkat keyakinan 95\% $(\alpha=0,05)$. Uji $F$ dapat dihitung dengan menggunakan rumus yaitu :

$$
\mathrm{F}=\frac{\mathrm{R} 2 / \mathrm{K}}{(1 \mathrm{R} 2) / \mathrm{n}-\mathrm{k}-1}
$$


Keterangan :

R2 : Koefesien determinasi

$\mathrm{N}$ : Jumlah Sample

$\mathrm{K}$ : Jumlah variable bebas

Dengan kriteria tersebut, diperoleh nilai Fhitung yang dibandingkan dengan Ftabel dengan tingkat resiko dalam hal ini 0,05 dan tingkat kebebasan $=\mathrm{n}-\mathrm{k}-1$.

Dimana :

$\mathrm{F}_{\text {hitung }}>\mathrm{F}_{\text {tabel }}=\mathrm{Ha}$ diterima dan $\mathrm{HO}$ ditolak $\mathrm{F}_{\text {hitung }}<\mathrm{F}_{\text {tabel }}=\mathrm{Ha}$ ditolak dan $\mathrm{H} 0$ diterima.

\section{HASIL DAN PEMBAHASAN}

\section{Pengujian Hipotesis}

Pengujian hipotesis ini untuk mengetahui ada atau tidaknya pengaruh Profitabilitas dan Likuiditas terhadap Return Saham. Hasil hipotesis yang menyatakan profitabilitas $\left(\mathrm{X}_{1}\right)$ dan likuditas $\left(\mathrm{X}_{2}\right)$ berpengaruh secara parsial dan simultan terhadap tingkat keuntungan saham, hasil atau keuntungan yang diperoleh pemegang saham sebagai hasil dari investasinya.

Berdasarkan nilai Adjusted $R$ Square pada tabel tersebut sebesar 0,185 . Hal ini menunjukkan bahwa 18,5\% variable Return saham (Y) atau tingkat keuntungan yang diperoleh yang diperoleh pemegang saham sebagai hasil dari investasinya, dapat dijelaskan oleh Profitabilitas melalui Rasio Return On Equity (ROE) dan Likuiditas melalui Current Ratio (CR). Sehingga sisanya sebesar $81,5 \%$ dipengaruhi oleh variabel lain yang tidak dijelaskan oleh model penelitian ini.

Berdasarkan model regresi yang dapat dibentuk adalah $Y=0,397+0,125 X_{1}+$ $0,104 X_{2}$. Taraf signifikansi 0,05 dan Derajat Kebebasan (DK) dengan ketentuan $=\mathrm{n}-1-\mathrm{k}$, atau $22-1-2=19$, dari ketentuan tersebut, diperoleh angka $t_{\text {tabel }}$ sebesar 2,0930. Kriteria uji hipotesisnya dapat dijelaskan jika $t_{\text {hitung }}>t_{\text {tabel }}=\mathrm{H}_{\mathrm{a}}$ diterima dan $\mathrm{t}_{\text {hitung }}<\mathrm{t}_{\text {tabel }}=\mathrm{H}_{\mathrm{a}}$ ditolak.

Berdasarkan hasil perhitungan, diperoleh angka $t_{\text {hitung }}$ Variabel Profitabilitas yang diukur dengan Return On Equity $\left(\mathrm{X}_{1}\right)$ sebesar 3,440 > $t_{\text {tabel }}$ sebesar 2,0930, sehingga $\mathrm{H}_{\mathrm{a}}$ diterima dan $\mathrm{H}_{0}$ ditolak. Artinya, pengaruh yang signifikan Profitabilitas yang diukur dengan Return On Equity (ROE) terhadap Return saham. Hal ini sesuai dengan nilai signifikansi sebesar 0,001 yang lebih kecil dari 0,05. Dengan demikian, Profitabilitas yang tinggi akan dapat meningkatkan Return saham perbankan.

Dan untuk angka thitung Variable Likuiditas yang diukur dengan Current Ratio $\left(\mathrm{X}_{2}\right)$ sebesar 2,004 < $\mathrm{t}_{\text {tabel }}$ sebesar 2,0930, sehingga $\mathrm{H}_{\mathrm{a}}$ ditolak dan $\mathrm{H}_{0}$ diterima. Artinya, pengaruh yang tidak signifikan Likuditas terhadap Return saham. Hal ini tidak sesuai dengan nilai signifikansi sebesar 0,049 yang jauh lebih kecil dari 0,05. Dengan demikian, Likuiditas yang baik akan dapat meningkatkan Return saham perbankan.

Hasil menunjukkan nilai $F_{\text {hitung }}$ adalah 8.380 dengan tingkat signifikansi 0,001. Sedangkan $\mathrm{F}_{\text {tabel }}$ pada tingkat kepercayaan 95\% $(\alpha=0,05)$ dengan $n-1-k$ adalah 3,52. Oleh karena pada perhitungan $F_{\text {hitung }}>F_{\text {tabel }}$ yakni $8.380>3,52$ sesuai dengan nilai signifikansi sebesar 0,001 yang lebih kecil dari 0,05. Maka hal ini menunjukkan bahwa pengaruh variable independen oleh profitabilitas dan likuiditas berpengaruh secara parsial dan simultan terhadap Return saham dapat diterima secara keseluruhan.

\section{Pembahasan Hasil Penelitian}

Setelah dilakukan pengujian selanjutnya akan dilakukan pembahasan untuk mengetahui apakah variabel-variabel bebas (independen) yang digunakan dalam penelitian ini secara parsial mampu menjelaskan variable terikat (dependen). 
Berdasarkan hasil perhitungan analisis regresi linier variabel Profitabilitas (X1) yang diukur denga Return On Equity (ROE)

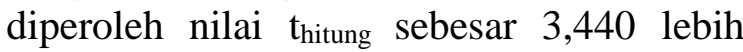
besar dari nilai $t_{\text {tabel }} 2,0930$ dengan tingkat signifikansi 0.001 lebih kecil dari taraf signifikansi $\alpha=0,05$. Oleh karena itu, secara parsial variable Profitabilitas mempunyai pengaruh yang positif dan signifikan terhadap Return saham.

Temuan penelitian ini, diperkuat dengan penelitian yang dilakukan oleh Mei Hotma Mariati Munte (2009) yang menemukan bahwa terdapat pengaruh yang signifikan faktor fundamental terhadap Return Saham. Dan diperkuat lagi dengan penelitian yang dilakukan dengan Aryadi Primandoko (2005) yang menyatakan adanya pengaruh likuiditas dan profitabilitas terhadap Return saham.

Dengan demikian Profitabilitas mempengaruhi tingkat keuntungan saham (Return Saham) yang akan diterima investor. Oleh sebab itu, perlu diperhatikan faktor-faktor yang mempengaruhi Profitabilitas sebuah Bank.

Berdasarkan hasil perhitungan analisis regresi linier variabel Likuiditas (X2) yang diukur denga Current Ratio (CR) diperoleh nilai thitung sebesar 2,004 lebih kecil dari nilai $t_{\text {tabel }}$ 2,0930 dengan tingkat signifikansi 0.049 lebih kecil dari taraf signifikansi $\alpha=0,05$. Oleh karena itu, secara parsial variable Likuiditas tidak mempunyai pengaruh yang signifikan terhadap Return saham.

Temuan penelitian ini, diperkuat dengan penelitian yang dilakukan dengan Mei Hotma Mariati Munte (2009) yang menyatakan tidak adanya pengaruh likuiditas yang diukur dengan Current Ratio (CR) dan Return saham.

Variable Likuiditas (X1) yang diukur dengan Current Ratio (CR) memiliki koefesien regresi bertanda positif sebesar 0,104 hal ini mengandung arti bahwa apabila nilai koefesien regresi variable lainnya tetap, maka perubahan variable tingkat Likuiditas sebesar $1 \%$ akan menaikkan besarnya tingkat Return saham sebesar 0,104. Hal ini bermakna bahwa mengukur kemampuan jangka pendeknya dengan melihat aktiva lancar.

Berdasarkan hasil perhitungan analisis regresi linier menunjukkan nilai $F_{\text {hitung }}$ adalah 8.380 dengan tingkat signifikansi 0,001. Sedangkan $F_{\text {tabel }}$ pada tingkat kepercayaan $95 \%(\alpha=0,05)$ dengan $n-1-k$ adalah 3,52. Oleh karena pada perhitungan $F_{\text {hitung }}>F_{\text {tabel }}$ yakni $8.380>3,52$ sesuai dengan nilai signifikansi sebesar 0,001 yang lebih kecil dari 0,05 . Maka hal ini menunjukkan bahwa pengaruh variable independen oleh profitabilitas dan likuiditas berpengaruh secara parsial dan simultan terhadap Return saham dapat diterima secara keseluruhan.

Temuan penelitian ini, diperkuat dengan penelitian yang dilakukan dengan Aryadi Primandoko (2005) yang menyatakan adanya pengaruh likuiditas dan profitabilitas terhadap Return saham.

Variable Profitabilitas $\left(\mathrm{X}_{1}\right)$ dan Likuiditas $\left(\mathrm{X}_{1}\right)$ memiliki koefesien regresi bertanda positif sebesar 1,093 hal ini mengandung arti bahwa apabila nilai koefesien regresi variable lainnya tetap, maka perubahan variable tingkat Likuiditas sebesar $1 \%$ akan menaikkan besarnya tingkat Return saham sebesar 1,093.

\section{KESIMPULAN DAN SARAN}

\section{Kesimpulan}

Berdasarkan hasil analisis data dan pengujian hipotesis yang telah dilakukan mengenai Pengaruh Profitabilitas dan Likuiditas terhadap Return Saham Perbankan yang Listing di Bursa Efek Indonesia 2008-2010, dapat diambil kesimpulan sebagai berikut :

1. Secara parsial, faktor yang berpengaruh secara signifikan terhadap Return 
saham adalah variabel Profitabilitas yang diukur dengan Return On Equity (ROE), sedangkan variabel Likuiditas yang diukur dengan Current Ratio (CR) tidak berpengaruh secara signifikan terhadap Return saham.

2. Ada pengaruh signifikan Profitabilitas dan Likuiditas terhadap terhadap Return Saham Perbankan yang Listing di Bursa Efek Indonesia 2008-2010.

\section{Saran}

Berdasarkan hasil analisis data dan pengujian hipotesis yang telah dilakukan mengenai Pengaruh Profitabilitas dan Likuiditas terhadap Return Saham Perbankan yang Listing di Bursa Efek Indonesia 2008-2010, maka peneliti memberi saran kepada investor dan manajemen perbankan sebaiknya mempertimbangkan serta memperhatikan faktor Profitabilitas dan Likuiditas yang secara simultan berpengaruh signifikan terhadap Return saham, terutama tingkat profitabilitas yang diukur dengan Return On Equity (ROE) sangat berpengaruh terhadap tingkat keuntungan saham yang akan diterima oleh investor serta memperhatikan tingkat Likuiditas guna menjaga kestabilan harga saham yang tinggi untuk memberikan keuntungan saham yang tinggi juga kepada para pemegang saham dan menarik calon investor.

\section{DAFTAR PUSTAKA}

Bursa Efek Indonesia. Indonesian Capital Market Directory 2008-2010. Jakarta: PT Bursa Efek Indonesia. www.idx.co.id.

Ghozali, Imam. 2013. Aplikasi Analisis Multivarite Dengan Program IBM
SPSS 21 Update PLS Regresi.

Semarang: Universitas Diponegoro.

Hery. 2013. Akuntansi Keuangan Menengah. Cetakan pertama. Yogyakarta: CAPS (Center of Academic Publishing Service).

Hery. 2014. Analisis Laporan Keuangan. Edisi Pertama, Cetakan Ke-2. Jakarta: Bumi Aksara.

Kasmir. 2011. Analisis Laporan Keuangan. Edisi ke-1, Cetakan ke-6. Jakarta: Rajawali Pers.

Munawir, 2012. Analisa Laporan Keuangan. Yogyakarta: Liberty.

Putra, Lutfi Jaya. 2012. Pengaruh Perputaran Modal Kerja Terhadap Profitabilitas. Jurnal Ekonomi Gunadarma. Vol.09, No.01.Pp 1-10.

Ristono, Agus. 2013. Manajemen Persediaan. Edisi Pertama. Cetakan ke-2. Yogyakarta: Graha Ilmu.

Riyanto, Bambang. 2011. Dasar Dasar Pembelanjaan Perusahaan. Edisi Keempat. Yogyakarta: BPFE.

Santoso, Singgih. 2010. Statistik Parametrik. Jakarta: PT. Elex Media koputindo.

Sugiyono. 2013. Metode Penelitian Bisnis (Pendekatan Kuantitatif, Kualitatif dan $R \& D)$. Bandung: Alfabeta.

Wolk, Harry I., Michael G. Tearney, dan James L Dodd. 2008. Accounting Theor: A Conceptual and Institusional Approach. SouthWestren: College Publishing. 